\title{
Competency-based Learning in Higher Mathematics Education as a Cluster of Efficient Approaches
}

\author{
Aprendizado Baseado na Competência Aplicado ao Ensino Superior da \\ Matemática como um Cluster de Abordagens Eficientes
}

\author{
Alexey A. Kytmanov ${ }^{*}$ \\ Michael V. Noskov ${ }^{* *}$ \\ Konstantin V. Safonov ${ }^{* * * *}$ \\ Marina V. Savelyeva ${ }^{* * * *}$ \\ Victoria A. Shershneva ${ }^{* * * *}$
}

\begin{abstract}
This paper presents the research results of what the process of mathematics teaching should be under the competency-based approach allowing the development of a university student's mathematical competency. It indicates that integrative structure of mathematical competency containing cognitive, practical, motivational and valuebased, reflexive and assessment-based components, updates the polyparadigm approach in teaching mathematics as an open cluster of approaches; their integrated utilization under the leading role of competency-based approach contributes to developing all mathematical competency components. It justifies that competency-based, context-based, interdisciplinary, discipline-based and information technology approaches and fundamentalization play a critical part in the polyparadigm approach; the integrated utilization of all approaches results in a synergetic effect. Within this framework the basic principles of competency-based mathematics teaching as well as a coherent system to select the content of mathematics teaching for engineering educational institution students are developed.
\end{abstract}

Keywords: Mathematical competency. Polyparadigm approach. Didactic basis. Cluster of approaches. System to select the content of mathematics teaching.

\section{Resumo}

Este artigo apresenta resultados de pesquisa sobre como deve ser o processo de ensino da Matemática dentro da abordagem baseada na competência de modo a possibilitar o desenvolvimento das capacidades matemáticas do estudante universitário. Os resultados indicam que a estrutura integrante da competência matemática, contemplando os aspectos cognitivo, prático, motivacional, valor intrínseco, reflexivo e avaliativo, confirma a abordagem poliparadigmática do ensino da Matemática como sendo um cluster aberto de abordagens; a utilização inte-

\footnotetext{
* Prof. Dr., Siberian Federal University, Department of Applied Mathematics and Computer Security, 79 Svobodny av., Krasnoyarsk, 660041 RUSSIA. E-mail: aakytm@gmail.com

** Prof. Dr., Siberian Federal University, Department of Applied Mathematics and Computer Security, 79 Svobodny av., Krasnoyarsk, 660041 RUSSIA. E-mail: mvnoskov@yandex.ru

**** Prof. Dr., Siberian State Aerospace University, Department of Applied Mathematics, 31 Krasnoyarsky Rabochy av., Krasnoyarsk, 660037 RUSSIA. E-mail: safonovkv@ rambler.ru

Assoc. Prof. Dr., Siberian State Aerospace University, Department of Foreign Languages in Engineering, 31 Krasnoyarsky Rabochy av., Krasnoyarsk, 660037 RUSSIA. E-mail: mvsavelyeva10@yandex.ru

${ }_{* * * * * * *}$ Prof. Dr., Siberian Federal University, Department of Applied Mathematics and Computer Security, 79 Svobodny av., Krasnoyarsk, 660041 RUSSIA. E-mail: vshershneva@yandex.ru
} 
grada dessas abordagens sob a óptica da competência contribui para o desenvolvimento de todos os componentes do domínio da matemática. A pesquisa justifica que as abordagens baseadas em competência, contexto, interdisciplinaridade, organização e tecnologia da informação desempenham um papel fundamental na abordagem poliparadigmática. A utilização integrada de todas as abordagens resulta em um efeito sinergético. Dentro desta estrutura, são desenvolvidos os princípios básicos do ensino da Matemática baseado na competência, assim como um sistema coerente para selecionar conteúdos de ensino para escolas de engenharia.

Palavras-chave: Competência matemática. Abordagem poliparadigmática. Base didática. Cluster de abordagens. Sistema para selecionar conteúdos de ensino.

\section{Introduction}

Defining the goals and results of modern higher education, the graduate's personal quality system guarantees the ability and readiness to making a career is researched as a unit. These personal qualities are integrated with the concept of professional competency that has become the goal and the result of higher education, and the competency-based approach is the leading approach to train higher education institution graduates (WARN; TRANTER, 2001; LUNEV, PETROVA; ZARIPOVA, 2013; JOHNSTONE; SOARES, 2014). It appears to be logical to determine the mathematical competency as a projection of the professional competency into the mathematics subject-matter discipline, extracting the graduate's personal qualities formed in mathematics training out of professional competence.

In the paper, we confront the problem of mathematical competency development. To have an answer to the following question: what kind of process, to train mathematics should be used under the competency-based approach to develop students' mathematical competency? Currently the problem has not completely been solved, because the distinctness, what basic principles of mathematics training are followed under the competency-based approach do not suffice; these principles could allow the development of content, forms, methods and means of mathematics training, as well as many university disciplines. The problem is determined by the fact that the competency-based approach defines the goal and result of education, which is its leading role, but it does not clearly determine coherent content, forms, methods and means of education (SOBIECHOWSKA; MAISCH, 2006; NOSKOV; SHERSHNEVA 2007; KIRKWOOD; PRICE, 2013; CARRILLO; CONTRERAS; ZAKARYAN, 2014). They should be developed by educators and researchers based on the goal and result of competency-based approach.

The solution of the problem is of importance of realizing the competency-based approach in practice, especially to develop a methodological framework to teach mathematics, physics, electrical engineering and other university disciplines contributing to an increase in 
quality of higher education. We would like to underline the characteristic aspects of an engineer's professional activity connected with complicated equipment and technologies, their fast upgrading, causing the increase of attention to the problem at higher engineering (technical) educational institutions (WILLIAMSON; MARTIN; SCHAUDER, 2003; NOSKOV; SHERSHNEVA, 2007).

The goal of this paper is to further the development of the theoretical foundations for students' mathematics training as future engineers from a perspective of the competencybased approach and the development of the foundations of the coherent methodological framework.

To achieve the goal the following problems are solved in the paper: to substantiate the importance of the polyparadigm approach, (JAKOBSEN; BUCCIARELLI, 2007; YORKE, 2011; HUMPHREY, 2013; WISMATH, 2013) consisting of the integrated utilization of various approaches in mathematics teaching under the leading role of the competency-based approach in the process of developing all mathematical competency components, (RAVEN, 1997; RAVEN, 2012); to construct a didactic basis of competency-based mathematics teaching; to substantiate the cluster structure of the polyparadigm approach; to develop the fundamental teaching principles based on the polyparadigm approach allowing to realize competency-based teaching; to develop the coherent system to select the content for mathematics teaching for engineering educational institution students.

\section{The study}

The stated problems are considered in the sections below. We substantiate the importance and appropriateness of the polyparadigm approach in mathematics teaching to higher educational institution students as the main methodological approach to develop mathematical competency. We develop the concept of mathematics teaching to engineering educational institution students based on the polyparadigm approach including the complex of basic teaching principles and coherent system to select teaching content as the main components of the methodological system for mathematics teaching.

\subsection{The Polyparadigm approach as the base to develop mathematical competency}

Our opinion is that the main aspect of the issue to develop mathematical competency coheres with the professional and mathematical competency structure, where the majority of 
researchers lay emphasis on cognitive, practical, motivational and value-based components as well as reflexive and assessment-based components (RAVEN, 1984; MACLELLAN, 2008; BATES; O'BRIEN, 2013). We believe developing these components provides for applying various approaches in teaching mathematics.

For instance, fundamentalization might be considered the main approach for the cognitive component of mathematical competency. That is the approach focused on improving the quality of a student's fundamental mathematics training: their basic, core knowledge and knowledge-on-long demand to ensure a graduate's readiness to apply the knowledge to changing professional activity; therefore, fundamentalization contributes to developing competency (DOERR; CHAMBERS; KEEFER, 2007; SCOTT; MORTIMER; AMETLLER, 2011).

The contextual approach is directly destined to develop practical component of mathematical competency. The essence of the approach is in modeling the professional and social context of students' future jobs in the process of their training (VERBITSKI, 1991; VERBITSKI, 2006). The contextual approach supplies students' personal involvement into the process of mathematics training, relevance of the training context, ability to apply pedagogical technologies, proposed by other approaches, and the cohesion of training and up-bringing of a professional personality (VERBITSKI, 2006).

Moreover, to develop motivational and value-based components the learner-centered and the contextual approaches are of great importance, they are both directed to develop and support student's relevant emotional sensory state including their cognitive performance (NOSKOV; SHERSHNEVA, 2007; FLEGG; MALLET; LUPTON, 2012).

Finally, reflexive and assessment-based components of mathematical competency is efficiently developed while using the learner-centered approach, when significant attention is paid to a student's self-analysis development as well as teaching skill to assess their own cognitive performance and correct the processes (VERBITSKI, 2006).

Therefore, we came to the conclusion that integrative mathematical competency structure predetermines the necessity of comprehensive application of various approaches in teaching, when all competency components are provided; the competency-based approach has the leading part.

Currently cumulative realization of several paradigms where the leading paradigm plays the dominating part, the other paradigms do not oppose but add to it according to the synergetic principle, this is considered the polyparadigm approach (JAKOBSEN; BUCCIARELLI, 2007; YORKE, 2011; HUMPHREY, 2013; WISMATH, 2013). In relation to this, 
we proclaim that the polyparadigm approach is comprehensive when applying various approaches in teaching mathematics and other university disciplines, such as those relying on different educational paradigms including the leading competency-based one as well as knowledge-based, learner-centered, system-based and practical competency and others. In this terminology, the above conclusion is the following: integrative competency structure foregrounds the polyparadigm approach as the main methodological approach in higher education as it allows the development of all of the students' competency components.

We believe the role of the polyparadigm approach is based on long-standing assumptions. Therefore, the cardinal tendency to develop approaches for mathematics teaching in Russian technical universities has been the progressive idea generation of multiapproach and polyparadigmality. Indeed, in Russian didactic research on the problems in mathematics teaching at higher engineering educational institutions since the beginning of 1980s, four big directions have been gradually formed; they assume the improvement of the quality of mathematics education on the ground of the contextual approach - contextual (professionally oriented) education, the interdisciplinary approach - applying interdisciplinary connections of mathematics, the discipline-based and information technology approach - applying computing techniques in mathematics training, and fundamentalization - the approach mentioned above. The researchers and educators have proved the efficiency of these approaches regarding many subject domains.

Although in the knowledge-based paradigm these approaches, excluding fundamentalization, were not in great demand or realized, as they were beyond its frame, further due to generating the competency-based approach in Russian higher education the idea of multiapproach and polyparadigmality has reinforced this. The majority of researchers have realized the contextual, interdisciplinary, discipline-based and information technology approaches and fundametalization as well as some other approaches have competency-based background and could be efficiently used to develop mathematical competency. It should be mentioned though, as before that these approaches are applied separately from each other in the process of mathematics teaching.

\subsection{Didactic basis of competency-based mathematics teaching}

In our opinion, admitting appropriateness of complex application of various efficient approaches in mathematics teaching under the leading role of the competency-based approach could become the next stage in the natural development of the idea of multiapproach and 
poliparadigmality in higher education. Besides, this stage gives another substantiation of the poliparadigm approach as the methodological base for developing students' mathematical competency.

To select the approaches for mathematics teaching to apply within the poliparadigm approach, we will follow the didactic classification proposed by I. A. Zimnyaya. According to her opinion, if one considers the teaching approaches "within the main pedagogy categories the goal, contents, form, method and means of teaching - it is possible to claim, all approaches could exist but mainly regarding separate categories among the above mentioned" (ZIMNYAYA, 2006). It could be noted that all pedagogic categories obtain different didactic commonality and they are presented in decreasing order. The correlation among them and the teaching approaches, pointed out by I. A. Zimnyaya, allows classification of the approaches due to their didactic commonality.

The competency-based approach evidently has the greatest commonality because it determines the goal and the result of mathematics teaching. It is linked with the content, forms, methods and means of teaching, but it determines them implicitly through description of students' competency to be developed through the teaching process. The four approaches studied above are the next due to commonality, as they conform to the teaching content level and explicitly impact its forming: the contextual, interdisciplinary, discipline-based and information technology approaches and fundamentalization. For example, according to the contextual approach the content of mathematics teaching are filled with professionally oriented elements.

The didactic commonality of an approach is characterized by its didactic potential, which could be realized in mathematics teaching. Therefore, the approach to form the contents has a greater impact on teaching results, than the approaches determining only forms and methods of teaching; the potential of the approach is higher, and it is more efficient than others are.

The great didactic potential of the contextual, interdisciplinary, discipline-based and information technology approaches and fundamentalization is determined by the fact, that each of them realizing one of the common didactic principles: professional orientation, interdisciplinary links, informatization and fundamentalization. These principles are singled out from the amount of common didactic principles by their factual support of competency development, being beyond the scope of knowledge-based paradigms in education; they have not been in demand and have not been realized to the right degree. Under the condition of knowledge-based learning these principles used to be common didactic de-jure, but not defacto. 
We believe the essence of transition from knowledge-based mathematics learning to competency-based learning is in complete realization of the stated four principles to achieve the goal and the result of the competency-based approach. Therefore, we consider the amount of all the principles of professional orientation, interdisciplinary links, informatization and fundamentalization to be the didactic basis of competency-based mathematics education.

It should be noted there are no other approaches able to influence the development of competency-based mathematics learning like this one, as currently there are no other common didactic principles obtaining competency-based background. Hence, within the polyparadigm approach frame it is viable to apply integrated competency-based, contextual, interdisciplinary, discipline-based and information technology approaches and fundamentalization as approaches obtaining the greatest didactic potential to estimate their efficiency.

Speaking about the issue of possibility for their integrated application, we consider it an issue to their compatibility, consistency of the contextual approach and fundamentalization. However, the problem has been favorably solved, it has been proved under contextual teaching that the quality of fundamental mathematical knowledge is improved (NOSKOV; SHERSHNEVA, 2007).

\subsection{Cluster structure of the polyparadigm approach}

It is at the educator's discretion to include other approaches in mathematics teaching into the polyparadigm approach: they could be of less didactic similarity, though corresponding to form levels, methods and training resources contributing to achieving goals and results of the competency-based approach, for example, project-oriented, problem-oriented or taskoriented.

Currently the amount of objects of split-level but having similar purposes, commonly called cluster, hence, it is possible to study the polyparadigm approach as an open consistent cluster of approaches in teaching, and its background is in integrated optimal use of approaches with the synergetic effect. The approaches are of various didactic potential: the competency-based approach, playing the leading part, as well as the other approaches according to their didactic potential - contextual, interdisciplinary, disciplinebased and information technology approaches and fundamentalization. Cluster openness understands that an educator can use different approaches within its frame, though with less di- 
dactic similarity, but contributing to achieving the goal and results of the competency-based approach.

It is important to integrate the application of these approaches, when they add deficient didactic components to each other it generates the synergetic effect. In this vein, the competency-based approach is completed with content, forms, methods and training resources allowing to achieve its goals and results; other approaches, developed within the knowledgebased paradigm, for example, contextual and interdisciplinary, are added with goals and results of the competency-based approach coherent to them and improving the results of their usage. For this reason, no single simple "arithmetic" addition of results of applying teaching approaches occurs, but simultaneous improves the results of each of them - the synergetic effect occurs, it reveals in greater nonlinear efficiency due to using these approaches.

Thus, we conclude that the competency-based mathematics learning of technical college and university students could be realized within the cluster of polyparadigm approach.

\subsection{Basic principles of competency-based mathematics training}

In the light of the above, we can consider the main principles of contextual, interdisciplinary, discipline-based and information technology approach and fundamentalization to be the basic principles of competency-based mathematics training.

The following principles suggest the basic principles of competency-based mathematics training according to the polyparadigm approach:

- training should be directed to develop fundamental core knowledge consisting of basic framework invariant knowledge in mathematics as a base to develop extended competency, that means the ability and readiness to apply the knowledge in the long-term under the conditions of changing professional life (the principle of prolonged competency);

- in the process of training mathematics it is necessary to simulate the professional context of the future job of a student (the principle of professional context);

- while training an educator the need to demonstrate the linkage of the learning material to practical issues beyond the scope of mathematics object field regularly that is in every topic (the principle of applied importance);

- in training it is recommended to use a wide range of mathematics linkage to other related and unrelated disciplines regularly creating situations of interdisciplinary usage of the knowledge in mathematics within the object-field of another discipline (the principle of 
interdisciplinary integration) (NOSKOV; SHERSHNEVA, 2008; GONÇALVES, PIRES, 2014);

- during the training process it is important to regularly develop the ability and readiness to apply information and communication technologies and knowledge in mathematics in an integrated manner to the professional life (the principle of discipline-based and information technology integration);

- in training and learning mathematics there is a possibility to quickly and efficiently evaluate the results for both an educator and a student, including constant student selfevaluation through means of the instruments located in the learner-centered educational milieu on the Internet (the principle of quick and efficient reflexivity);

- in training an educator the need to sequentially practice the historically reasonable experience of using the knowledge in mathematics within the process of development of the science field and its applications (the principle of historical continuity).

These principles become a theoretic fundamental for developing content, forms, methods and tools of mathematics training for students of engineering university based on the polyparadigm approach.

\section{The system for the selection of content of competency-based mathematics training}

As a system of mathematics training content selection, we propose a three-stage model consisting of the system of the ranked criteria choice, where the didactic requirements to the content is specified and concretized. We present the system by a disjunctive-conjunctive formula.

The criteria of the first rank of the selection system are the most important didactic requirements directly linked to observing competency-based, contextual, interdisciplinary approaches as well as discipline-based and information technology approach and fundamentalization:

- the content of mathematics teaching should consist of a fundamental framework of scientific knowledge contributing to development of a student's thematic thinking (the first rank criterion $A_{1}$ );

- the content of teaching should include the elements of an applied orientation, reflecting the main objectives of graduate's professional activity, considering an engineer's system of operation and allowing the development of a quasiprofessional occupation (criterion $\left.A_{2}\right)$; 
- the teaching content should reflect mathematics links to other disciplines, containing the situations of interdisciplinary application of knowledge (criterion $A_{3}$ );

- the content should allow the use information and communication technologies in the process of applying knowledge in mathematics to solve educational professionally oriented, interdisciplinary, and applied problems while being taught mathematics (criterion $A_{4}$ ).

The first stage of selecting the basis for the mathematics teaching content is formed by a logical sum, disjunction of the first rank criteria, while the content of education includes the teaching material sufficing at least one of the criteria that will naturally lead to the redundant content.

Furthermore, the content is necessary to specify and eliminate the redundant components; the result is achieved by setting an aggregate of selecting criteria of the second rank. These criteria are:

- easy-to-understand criterion - the content of teaching should be easy to understand by the students (criterion of the second rank $B_{1}$ );

- the optimal combination criterion of fundamentalization, professional orientation and interdisciplinary nature in mathematics teaching (criterion $B_{2}$ );

- learner-centered criterion - under equal terms it is necessary to prefer the content which has an impact on a student's emotionally sensuous state (criterion $B_{3}$ );

- prospective criterion - under equal terms it is essential to include elements of the developing theories into the content, which will be in demand in the nearest future (criterion $B_{4}$ ).

What it means is that all the second rank criteria need to be applied to the content developed at the first stage. Therefore, we are referring to the conjunction, intersection of the second rank criteria; that constructs the second stage of the content.

The final third stage of concretization and further narrowing the content scope in mathematics teaching is done with an aggregate of the third rank selecting criteria:

- the correspondence criterion of educational information amount to the study time for the discipline $\left(C_{1}\right)$;

- the minimal sufficiency criterion - good content is not the only when we may not add something but also when we cannot extract anything without the loss of quality $\left(C_{2}\right)$;

- the minimal complexity criterion - under equal terms, the educational material obtaining the least complexity for both perception and learning is chosen $\left(C_{3}\right)$. 
The content formed at the first and second stages are completed with all criteria of the third rank in the form of their conjunction and intersection, which constructs the third stage of the content selection.

Therefore, the system to select the content of competency-based mathematics training at the higher engineering educational institutions based on the polyparadigm approach $(S)$ can be presented by the disjunctive-conjunctive formula:

$$
S=\left(A_{1} \vee A_{2} \vee A_{3} \vee A_{4}\right) \wedge\left(B_{1} \wedge B_{2} \wedge B_{3} \wedge B_{4}\right) \wedge\left(C_{1} \wedge C_{2} \wedge C_{3}\right),
$$

the formula, due to associativity and commutativity of conjunction and disjunction operations, correlates with the fact that the second rank and the third rank criteria can be applied successively in any order.

According to the engineering training directions (TOSMUR-BAYAZIT; UBUZ, 2013) an educator can complete the system of content selection with other criteria from the second and the third ranks.

Testing for the developed mathematics training principles and the corresponding system of the content selection occurred at Siberian Federal University (SFU) for teaching mathematics to the students - would-be engineers. It demonstrated good results for developing mathematical competency (CARR; BOWE; NI FHLOINN, 2013; FAULKNER; HANNIGAN; FITZMAURICE, 2014).

\section{Conclusion}

This research has demonstrated the integrative structure of students' mathematical competency, where cognitive, practical, motivational and value-based components as well as reflexive and assessment-based component are the main to focus on, the structure leads to the necessary integrated use of different approaches to mathematics teaching. This contributes to developing all mathematical competency components including the approaches based on various educational paradigms; it can be considered a polyparadigm approach for mathematics teaching according to the terminology used.

The essence of the transition from the knowledge-based mathematics learning to competency-based learning consists of the complete realization of common didactic principles: professional orientation, interdisciplinary links, informatization and fundamentalization. These principles were not in demand and were not obtained under the knowledge-based learning. The stated common didactic principles can be addressed as the didactic basis of competency-based mathematics learning. 
The research of the polyparadigm approach structure in mathematics teaching to engineering students has shown that we can consider it as an open consistent cluster of approaches in training. The essence of that is in the integrated, optimal, synergetic and effective usage of approaches obtaining different didactic potential: the competency-based one playing the leading part as well as the contextual, interdisciplinary, discipline-based and information technology approaches and fundamentalization. The next approaches according to their didactic potential contribute to developing the mathematics teaching content to estimate their efficiency. Within the cluster the other approaches can be used as the ones defining forms, methods and tools of mathematics training and contributing to achieving the goal and the result of the competency-based approach.

Based on the main training principles within the contextual, interdisciplinary, discipline-based and information technology approaches and fundamentalization, the basic principles of competency-based training on many university disciplines and disjunction-conjunction system of the content selection are shaped; they were successfully tested for teaching mathematics at SFU.

Thus, competency-based mathematics learning at higher engineering educational institutions can be done completely within the frame of the polyparadigm approach as the described cluster of the efficient approaches.

\section{References}

BATES, P.; O'BRIEN, W. It's more than stick and rudder skills': an aviation professional development community of practice. Teaching in Higher Education, London, v. 18, n. 6, p. 619-630, 2013.

CARR, M.; BOWE, B.; NI FHLOINN, E. Core skills assessment to improve mathematical competency. European Journal of Engineering Education, London, v. 38, n. 6, p. 608-619, 2013.

CARRILLO, J., CONTRERAS, L. C., ZAKARYAN, D. Opportunities to learn and mathematics competences: two case studies. Bolema: Mathematics Education Bulletin, Rio Claro, v. 28, n. 48, p. 89$109,2014$.

DOERR A.; CHAMBERS, E.; KEEFER, M. The changing role of knowledge in education? Education, Knowledge and Economy, London, v. 1, n. 3, p. 279-300, 2007.

FAULKNER, F.; HANNIGAN, A.; FITZMAURICE, O. The role of prior mathematical experience in predicting mathematics performance in higher education. International Journal of Mathematical Education in Science and Technology, London, v. 45, n. 5, p. 648-667, 2014.

FLEGG, J,; MALLET, D.; LUPTON, M. Students' perceptions of the relevance of mathematics in engineering. International Journal of Mathematical Education in Science and Technology, London, v. 43, n. 6, p. 717-732, 2012. 
GONÇALVES, H. J. L.; PIRES, C. M. C. Mathematical education in mid-level professional education: analysis of opportunities for interdisciplinary approaches. Bolema: Mathematics Education Bulletin, Rio Claro, v. 28, n. 48, p. 230-254, 2014.

HUMPHREY, C. A Paradigmatic Map of Professional Education Research. Social Work Education, London, v. 32, n. 1, p. 3-16, 2013.

JAKOBSEN, A.; BUCCIARELLI, L. Transdisciplinary Variation in Engineering Curricula. Problems and Means for Solutions. European Journal of Engineering Education, London, v. 32, n. 3, p. 295 301, 2007.

JOHNSTONE, S.; SOARES, L. Principles for Developing Competency-based Programs. Change: the Magazine of Higher Learning, London, v. 46, n. 2, p. 12-19, 2014.

KIRKWOOD, A.; PRICE, L. Missing: evidence of a scholarly approach to teaching and learning with technology in higher education. Teaching in Higher Education, London, v. 18, n. 3, p. 327-337, 2013.

LUNEV, A.; PETROVA, I.; ZARIPOVA, V. Competency-based models of learning for engineers: a comparison. European Journal of Engineering Education, London, v. 38, n. 5, p. 543-555, 2013.

MACLELLAN, E. The significance of motivation in student-centered learning: a reflective case study. Teaching in Higher Education, London, v. 13, n. 4, p. 411-421, 2008.

NOSKOV, M. V.; SHERSHNEVA, V. A. Interdisciplinary integration in Competency-based Approach. Vyssheye Obrazovaniye Segodnya, Moscow, n. 9, p. 23-25, 2008.

NOSKOV, M. V.; SHERSHNEVA, V. A. The Mathematics Education of an Engineer: Traditions and Innovations. Russian Education and Society, New York, v. 49, n. 11, p. 70-84, 2007.

RAVEN, J. Competence in Modern Society: its Identification, Development and Release. 2. ed. New York: Royal Fireworks Press, 1997.

RAVEN, J. Toward Professionalism in Psychology of Education. The Psychology of Education Review, London, v. 36, n. 1, p. 3-18, 2012.

SCOTT, P.; MORTIMER, E.; AMETLLER, J. Pedagogical link-making: a fundamental aspect of teaching and learning scientific conceptual knowledge? Studies in Science Education, London, v. 47, n. 1, p. 3-36, 2011.

SOBIECHOWSKA, P.; MAISCH, M. Work-based learning: in search of an effective model. Educational Action Research, London, v. 14, n. 2, p. 267-286, 2006.

TOSMUR-BAYAZIT, N.; UBUZ, B. Practicing engineers' perspective on mathematics and mathematics education in college. Journal of Science, Technology, Engineering and Mathematics Education, Auburn, v. 14, n. 3, p. 34-40, 2013.

VERBITSKI, A. A. An Active Learning in Higher School: the Contextual Approach. Moscow: Znaniye, 1991.

VERBITSKI, A. A. The Contextual Learning in Competency-based Approach. Vyssheye Obrazovaniye v Rossii, Moscow, n. 11, p. 70-84, 2006.

WARN, J.; TRANTER, P. Measuring Quality in Higher Education: a competency approach. Quality in Higher Education, London, v. 7, n. 3, p. 191-198, 2001. 
WILLIAMSON, K.; BANNISTER, M.; SCHAUDER, D. Developing an Interpretative Approach to Competency-Based Training and Learning. Australian Academic and Research Libraries, Canberra, v. 34, n. 2, p. 150-163, 2003.

WISMATH, S. Shifting the Teacher-Learner Paradigm: teaching for the 21st Century. College Teaching, Philadelphia, v. 61, n. 3, p. 88-89, 2013.

YORKE, M. Work-engaged learning: towards a paradigm shift in assessment. Quality in Higher Education, London, v. 17, n. 1, p. 117-130, 2011.

ZIMNYAYA, I. A. Competency-based Approach. What is it's Place in a System of Modern Approaches to Education Problems? Vysheye Obrazovaniye Segodnya, Moscow, n. 8, p. 20-26, 2006.

Submetido em Novembro de 2015. Aprovado em Abril de 2016. 